\title{
Development of cabozantinib for the treatment of prostate cancer [Corrigendum]
}

Vaishampayan UN. Core Evidence. 2014;9:61-67.

On page 62, line 6 of the Introduction section and page 67, line 2 of the Disclosure statement, "Exelexis Inc." should read "Exelixis Inc.".

\section{Publish your work in this journal}

Core Evidence is an international, peer-reviewed open-access journal evaluating the evidence underlying the potential place in therapy of drugs throughout their development lifecycle from preclinical to postlaunch. The focus of each review is to evaluate the case for a new drug or class in outcome terms in specific indications and patient groups.
The manuscript management system is completely online and includes a very quick and fair peer-review system, which is all easy to use. Visit http://www.dovepress.com/testimonials.php to read real quotes from published authors. submit your manuscript | www.dovepress.com

Dovepress

http://dx.doi.org// 0.2/47/CE.S67095 